\title{
Planning of Country Border Area as A Tourism Destination in Jayapura City
}

\author{
Nelman Rumere ${ }^{1}$, Agung Suryawan Wiranatha², \\ Ida Bagus Gde Pujaastawa ${ }^{2}$ \\ ${ }^{1}$ Master Program in Tourism, Udayana University \\ ${ }^{2}$ Center of Excellence in Tourism, Udayana University \\ Corresponding Author: nelmanrumere@gmail.com
}

\section{ARTICLE INFO \\ Received \\ 3 September 2020 \\ Accepted \\ 18 September 2020 \\ Available online \\ 30 September 2020}

\begin{abstract}
This article investigates and identifies the involvement of stakeholders, analyzes internal and external factors that influence the planning of country border areas, and formulates strategies and programs for developing national border areas. This study used qualitative methods with IFE, EFE, IE and SWOT analysis. Data collection was carried out by observation, interviews, documentation study, literature study, and FGDs. The number of informants was 13 people who are competent and chosen deliberately. The results of this study indicate that the country border area is in a medium internal and external position, meaning that the border area of the country is in quadrant $\mathrm{V}$, the strategy in quadrant $\mathrm{V}$ is to hold and maintain. Quadrant V indicates that the border area has developed and needs to be maintained. Therefore, the right grand strategies to be applied are market penetration and product development. Strategies and programs for developing country border areas with the Strengths-Opportunities strategies are mapping and polarization of tourist attractions, maximizing the types and diversity of tourism products in the border areas of the country, and evaluating cross-border festivals. Development programs by Weaknesses-Opportunities analysis are dissemination and training for human resource development particularly for the local people, construction of public facilities, tourism infrastructure, and coordination between stakeholders, and development programs. Meanwhile, by Weaknesses-Threats analysis, namely focus group discussions, seminars, workshops, entrepreneurship training, formal education for the local youths, security and cleanliness of tourist attractions, and regulatory evaluation.
\end{abstract}

Keywords: Regional planning, tourist destinations, country borders 


\section{INTRODUCTION}

Tourism is one of the non-oils and gas sectors that has a positive impact on the economy, especially contributing to earning foreign exchange. Tourism also provides job opportunities for the community in general and tourism in particular can provide business opportunities for local communities. The government is currently starting to plan the border area of the country as the frontier of the country as well as making the border area a cross-border tourist destination. One of the country's border areas currently planned and developed by the government is the border between Indonesia and PNG (Papua New Guinea).

The border between Indonesia and Papua New Guinea is located in the city of Jayapura, precisely in Skouw Village, Muara Tami Sub-District. The area has potential for various tourist attractions, but there are four main tourist attractions that are well-known and visited by tourists, including artificial tourist attractions such as state border monuments, cross-border markets, and cross-border festivals, while its natural tourist attractions, namely Holtekam Beach. The border monument between Indonesia and Papua New Guinea has become the country's icon but has also become a tourist attraction that attracts domestic tourists, local tourists and foreign http://ojs.unud.ac.id/index.php/eot tourists, especially tourists from Papua New Guinea. The cross-border market is currently a shopping attraction, which is often visited by foreign tourists from Papua New Guinea. Papua New Guinean tourists who shop at border markets have a very positive impact on the local community, because these tourists spend a lot of money to shop for various Indonesian products that are traded by local people.

Another man-made tourist attraction is entertainment tourism such as a cross-border festival event which is planned by the Ministry of Tourism to increase the number of tourists visits as much as possible through cross-country borders. The cross-border festival activities have a very positive impact, because these activities attract a large number of tourist arrivals from Papua New Guinea to Indonesia. The development of national border tourism needs to be supported by the availability of accessibility, public facilities and tourism infrastructure. The availability of accessibility and public facilities has been built and provided by the government to facilitate the movement of community and tourist activities in the border areas, while the availability of tourism facilities and infrastructure such as accommodation, restaurants, bars, caffetaria, souvenir shops, and other tourism facilities is not yet available, so a strategy is needed. and planning an appropriate tourism program so 
that tourism facilities and infrastructure can be immediately built so that they can support tourism activities in the border areas of the country.

The border area of the country is usually prone to conflict, so the security system needs to be improved so that it is safe for every tourist and local people who have activities in the area. Cleanliness and sanitation in each tourist attraction need to be paid attention to by the government and local communities in order to provide a good image for every visitor traveling in the border area of the country. The involvement and synergy of various parties such as the central government, the Jayapura City government, the Papua Province government, regional tourism associations such as ASITA, the Indonesian Hotel and Restaurant Association (PHRI), tourism consultants, tourism academics, and indigenous peoples' institutions need to be improved so that the border area of the country can be optimally developed. Regulations related to the development of country border areas need to be well planned by the central government and local governments in order to provide legal certainty for local communities, investors, and tourists.

Other most important aspects that need to be considered in planning the development program of the border areas of the country are the socio-cultural aspects http://ojs.unud.ac.id/index.php/eot and wisdom of the local community, environmental aspects, economic aspects of local people, political aspects between the two countries, and legal and human rights aspects of the two countries. These aspects need to be planned properly according to the conditions and development of the border areas of the country, so that in the future the development of border areas can develop properly.

This article analyzes the involvement of stakeholders related to the planning and development of the country's border areas, analyzes the internal and external factors that affect the planning of the country's border areas, and determines the development program strategy that will be carried out according to the developments and conditions of the border areas.

\section{THEORY AND METHOD}

The theory used in relation to this research is Butler's (1980) tourism area life cycle theory and tourism planning theory and uses IFE, EFE, IE and SWOT analysis. The tourism area life cycle theory is used to study and analyze the development phases of the country's border areas, while the tourism planning theory is used to analyze the strengths, weaknesses, opportunities, and threats resulting in a development program for the border area. The tourism 
area life cycle theory distinguishes several stages in tourism development, which consists of seven stages, namely the discovery stage, the involvement stage, the development stage, the consolidation stage, the stagnation stage, the decline stage, and the stage of rejuvenation.

Based on Butler (1980) theory analysis, the theory is then implemented according to conditions, facts and developments in the field. It is concluded that the country border area in Jayapura City is in the phase or stage of involvement, which means that there are four possibilities that will occur at this stage, namely (1) there is control from the local community, so far, the management system for the potential tourist attraction of the border area is still managed. by local people without the involvement of private parties or foreign investors.

The physical development of tourism such as hotels, bars, restaurants, cafes and other tourism facilities has not yet been built. (2) an increase in the number of tourist visits, at this stage it can be seen that the tourists who end up in the border areas of the country so far are less significant, especially foreign tourists, although there are visits, they can be found at certain times. While there are quite a lot of domestic tourist visits, but usually these tourists visit on holidays or are found when cross-border events such as cross-border http://ojs.unud.ac.id/index.php/eot festivals and trade border activities are held. (3) an area becomes a tourist destination marked by the start of promotion, this can be seen that the government is starting to synergize with regional tourism associations or institutions to jointly engage in promoting potential tourist attractions in the border areas of the country. (4) the existence of an initiative from the local community to develop their area, this stage can be illustrated that the community begins to form customary institutions to create cultural activities such as starting to develop art and dance, opening micro-businesses, initiatives to develop local products as culinary delights, developing a creative economy, as well as taking the initiative to maintain cleanliness and security in the border areas of the country.

IFE, EFE, and IE analyzes are used to analyze internal and external factors in order to determine the right strategy related to product development and market penetration. SWOT analysis is used to identify potential tourist attractions as well as to analyze internal factors consisting of strengths and weaknesses, and to analyze external factors consisting of opportunities and threats so that these factors are used as a basis for determining management strategies and development programs for border areas. This analysis begins by identifying the potential for tourism and 
related factors such as strengths and weaknesses. In the formulation of the strategy, an important role is focused on the involvement of stakeholders so that tourism potential is well developed and contributes to local communities and gives a good impression to every visitor or tourist. Another aspect that needs to be considered in the strategy is tourism facilities and infrastructure, because with the tourism infrastructure it can make it easy for tourists then the other most important focus is the development of human resources, because with the presence of human resources, local communities can develop their potential natural resources.

Data collection techniques and methods were carried out by means of observation, interviews, documentation study, and FGDs (Focus Group Discussions). Primary data were obtained from the results of the FGD and the results of interviews with competent and deliberately selected informants; the number of informants was 13 people. Secondary data is in the form of regulatory documents, basic agreements between the two countries, strategic planning for the development of state border areas, and profile documents of state border areas. The collected data were analyzed using IFE, EFE, IE, and SWOT matrices. Tourism facilities such as accommodation, restaurants, bars, cafeterias, souvenir http://ojs.unud.ac.id/index.php/eot shops, and other tourism facilities are minimal or even unavailable. Correct and effective policies and regulations are needed and it is necessary to increase the synergy of the central government, local governments and other parties involved in the development of the country's border areas. So far, the government has only focused on the construction of public facilities, while tourism facilities and infrastructure have not been given attention, which sometimes affects tourist activities in the border areas of the country.

Planning for a tourism area requires several things, such as the direction of the function area, space direction, facility and utility plans, transportation plans, indication of priority area programs, and activity development plans (Ariani and Suryawan 2018). Planning for the border areas of the country is expected to continue to be developed through adjustments to regulations so as to have a positive impact on the acceleration of infrastructure development in border areas in order to improve communities in the border areas of the country (Sholihah 2016). Meanwhile, according to (Page 2009) that the physical spatial approach, this approach is based on geographic land use traditions, development strategies based on different planning through spatial principles. For example, the grouping of visitors in an area, and these solutions are to avoid conflict. 


\section{RESULTS AND DISCUSSION}

\section{Stakeholders Involvement}

Planning and developing potential tourism resources in the border areas of the country need stakeholder involvement. The involvement of the stakeholders referred to in this paper is as follows:

a. Government

Government involvement in the planning and development of state border areas is to carry out physical development and non-physical development. The physical construction planned and built by the government is the construction of bridges, roads, international terminals, animal health quarantine buildings and human health clinics, clean water supply, telecommunication facilities, lighting (electric power), as well as carrying out other physical constructions intended for tourist activities and people in the border area of the country. Non-physical development carried out by the government, namely the development of human resource capacity such as conducting tourist attraction management training, training in managing local food into culinary delights, entrepreneurial training, disseminating immigration regulations for stakeholders involved in planning and developing country border areas, disseminating regulations and laws for communities in state border areas, http://ojs.unud.ac.id/index.php/eot dissemination of cross-border provisions between countries both traditionally and internationally, disseminating cross-border ownership of identity cards for citizens in country border areas, fostering national insight and national awareness, training related to efforts to return border crossers, improve legal order and administrative order regarding the citizenship status of country border residents.

b. Regional Tourism Associations / Institutions

The involvement of ASITA (Association of the Indonesia Tours and Travel Agency) Papua is to assist the government in increasing tourism promotion in the border areas of the country. The involvement of the HPI (Indonesian Tour Guides Association) in the Papua region is to conduct tour guide training for the community, especially local people who come from border areas. The involvement of the Papua LPKP (Institute for Research and Tourism Consultancy) is to conduct research related to the development of the border tourism market segment, conduct surveys and identify tourist attractions in the border areas, identify diversification of tourism products, and conduct research related to the motivation of tourists visiting the border areas. 


\section{c. Community}

The involvement of local communities in the development of state border areas is to support government programs in increasing human resource capacity. The community's participation, for example, has taken part in training in the tourism sector, such as training in tourist attraction management, training for local guides, culinary training with local ingredients, entrepreneurship training, and other trainings held by the government. Other involvement of the local community is participating in providing ideas and input to the government regarding the development of the country's border areas as well as maintaining the security situation, and maintaining the cleanliness of the attractive environment of the border areas.

\section{Factors Affecting the Development of Country Border Areas}

Internal factors that influence the development of the border areas of the country, namely the human resources of the local community, the availability of public facilities, the availability of tourism infrastructure, and coordination between stakeholders, to analyze these internal factors the IFE matrix is used. The IFE matrix results show that the main strength of the border areas is easy access with a value of 0.101 , while the main weakness http://ojs.unud.ac.id/index.php/eot factor of the border areas is the lack of availability of tourism facilities with a value of 0.079 . The IFE matrix results show a total value of 2.94, which means that the border area of the country has an average internal position. External factors that influence the development of border areas are security, regulations, tourists, crossborder permits, and public transportation, to analyze these external factors the EFE matrix is used. The EFE matrix results show that the main opportunity for the border area is millennial tourists with a value of 0.111 , while the main threat factor is security, such as drug trafficking and illegal firearms trade with a value of 0.103 . The EFE matrix shows a total value of 2.90, which means that the country's border area is in a medium external position.

Matching stage, at this stage the IE matrix is used. Based on the IE matrix, it can be seen that the $\mathrm{x}$-axis (total IFE value) is 2.94 and the y-value axis (EFE total value) is 2.90. This scale shows that the border area of the country is in quadrant $\mathrm{V}$, the strategy in quadrant $\mathrm{V}$ is to hold and maintain. Quadrant $\mathrm{V}$ shows that the country border area in Jayapura City has developed and needs to be maintained, so the right strategies to be applied are market penetration and product development. The details are shown in Figure IFE and EFE matrices. 
- Backward, forward or horizontal integration

- Market penetration

- Market development

- Product development

THE IFE TOTAL WEIGHTED

Growth and coaching
Strong

3.0 to 4.0

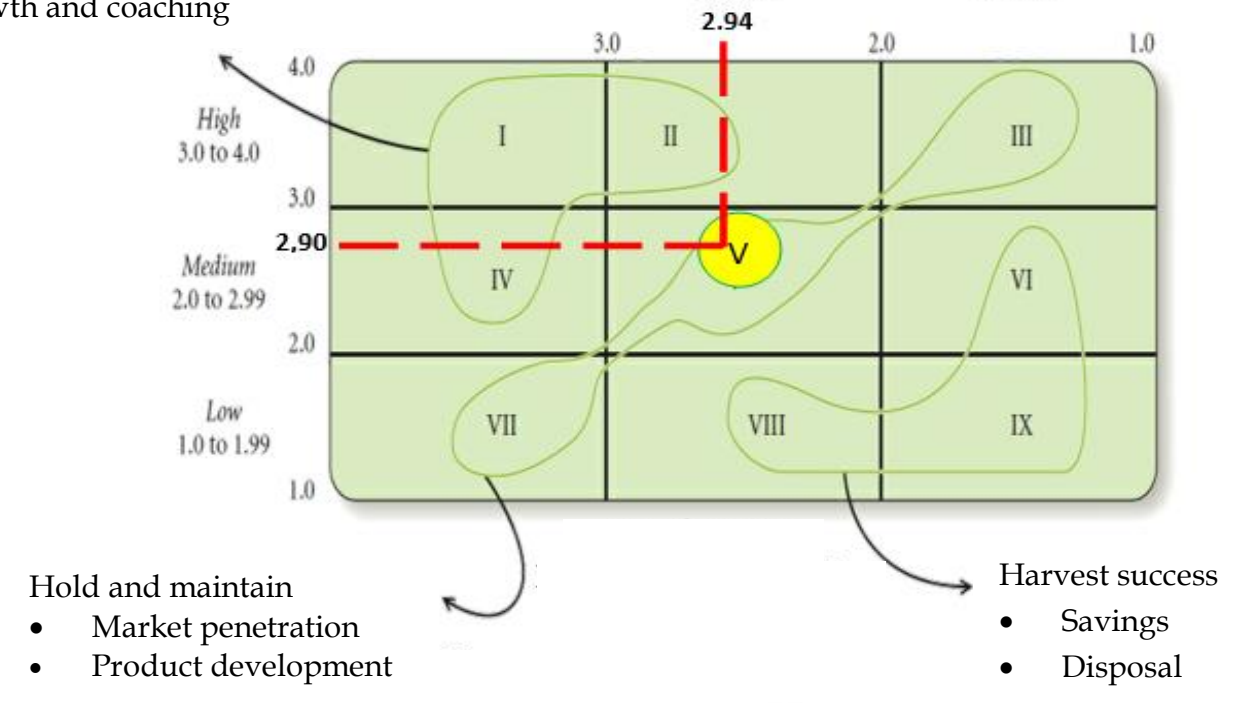

Figure 1. The results of the IFE and EFE matrix analysis (Source: David, 2017)

The results of the study concluded that the country border area in Jayapura City has natural, cultural, and man-made tourist attractions. The development of national border tourism is currently in the involvement stage, which means that there are four possibilities that will occur, namely (1) there is control from the local community, so far the management system for the potential tourist attraction of the border area is still managed by the local community without the involvement of the private sector. or investors from abroad. The physical development of tourism such as hotels, bars, restaurants, cafes and other tourism facilities has not been built. (2) http://ojs.unud.ac.id/index.php/eot
Increasing the number of tourist visits, at this stage it can be seen that the tourists visiting the border areas of the country have so far been less significant, especially foreign tourists, although there are visits, they can be found only at certain times. Meanwhile, there are quite a lot of domestic tourist visits, but they visit on holidays or when cross-border events are held, such as cross-border festivals and trade border activities. (3) An area becomes a tourist destination that begins with a promotion, this can be seen that the government is starting to synergize with regional tourism associations or institutions to jointly engage in promoting potential 
tourist attractions in the border areas of the country. (4) There is an initiative from the local community to develop their area, this stage can be illustrated that the community begins to form customary institutions to create cultural activities such as starting to develop art and dance, opening micro businesses, initiatives to develop local products as culinary delights, developing the economy. creative, as well as taking the initiative in maintaining cleanliness and security in the border areas of the country.

In order for the tourism potential of developing country borders to be maximized, it is necessary to involve the government, regional tourism associations, local communities, and the private sector (investors). Education such as training, dissemination, seminars, workshops need to be carried out in order to provide knowledge for local communities in exploiting the potential of tourism resources in the border areas of the country. Regulations related to the development of tourism in the border areas of the country need to be studied and evaluated so that there is legal certainty for tourists, investors and the public in carrying out activities in the border areas of the country.

\section{Planning Strategy and Development Program}

To identify problems with developing potential tourist attractions in the border areas of the country, it is necessary to study and discuss internal and external factors as follows:

\section{a. Internal Factors}

Internal factors that influence the development of state border areas are the factors of strength and weakness. Strength factors, including the national border monument, local community culture, natural tourist attractions (beaches, mountains, and forests), cross-border markets, and access from downtown Jayapura to the country border area. Weakness factors include public facilities, tourism facilities and infrastructure, local human resources, local people's understanding of tourism awareness, and coordination between stakeholders.

\section{b. External Factors}

External factors that influence the development of the country's border areas consist of opportunities and threat factors. Opportunity factors include tourists, diversification of tourism products, crossborder festivals, local people's economic income, and local community employment opportunities (participation). Threat factors are security, regulation, cross-border permits, and public transportation. 
The internal and external factors above were analyzed using SWOT matrix analysis, which can be seen in Table 1 .

Table 1. SWOT Matrix Analysis for Country Border Area Development

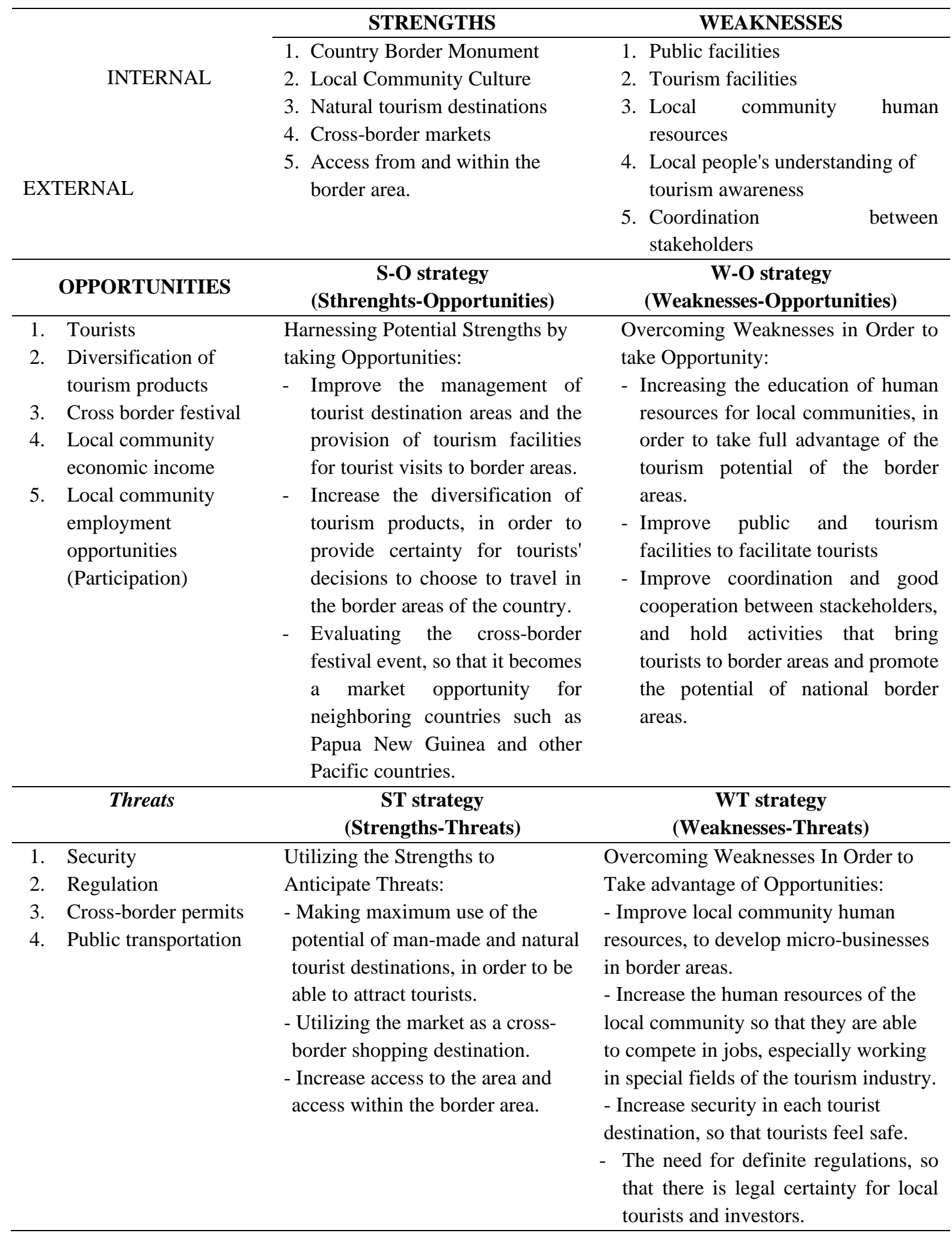

Source: Rangkuti, 2001 
Based on the data in the matrix above, each strategy used is described as follows:

a. The SO (Sthreangths-Opportunities) strategy, makes a special polarization mapping of tourism development in the border areas of the country, maximizes the types and diversity of tourism products in the border areas of the country, and evaluates cross-border festivals in order to increase the number of tourist visits from Pacific countries through cross-border countries.

b. WO (Weaknesses-Opportunities) strategy, dissemination and training of human resource development, especially local communities, construction of public facilities and special tourism facilities, and improving coordination between stakeholders.

c. ST (Strengths-Threats) strategy, optimizing cross-border market economic activity, and providing access to and within country border areas that connect tourist attractions to one another.

d. The WT (Weaknesses-Threats) strategy, conducts focus group discussions, seminars, workshops, training local communities for entrepreneurship, improves formal education for local youth, collaborates with other parties such as environmental activists, government http://ojs.unud.ac.id/index.php/eot and other private parties related to waste management in every tourist attraction, and existing regulations should be re-evaluated.

\section{Development Program}

The country border area development program is described based on the strategy of Strengths-Opportunities, WeaknessesOpportunities, and Weaknesses-Threats.

a. Development programs with StrengthsOpportunities: mapping and polarization of tourist attractions in the border areas of the country, maximizing the types and diversity of tourism products in the border areas of the country, and evaluating cross-border festivals.

b. Development program with Weaknesses-Opportunities: dissemination and training of human resource development, especially local communities, construction of public facilities, tourism infrastructure, and coordination between stakeholders.

c. Development program with StrengthsThreats: optimizing cross-border market economic activity and providing access to and within the country's border areas.

d. Weaknesses-Threats development program: focus group discussions, seminars, workshops, entrepreneurship training, formal education for local youth, safety, and hygiene of tourist 
attractions, evaluation, and enforcement of regulations.

\section{CONCLUSIONS AND SUGGESTIONS}

\section{Conclusions}

Based on the above analysis, it can be concluded that the land border area between countries in Skouw, Jayapura City has potential tourist attractions, such as natural tourism attractions, cultural tourism attractions, and man-made tourist attractions. The development of national border tourism areas requires the involvement of various parties, such as the government regarding regulations, physical development and nonphysical development.

Regional tourism associations or institutions such as ASITA related to tourism promotion in border areas, the Indonesian Tour Guides Association regarding tour guide training for local communities, Papua's LPKP (Tourism Research and Consultancy Institute) related to tourist attraction identification surveys, tourism market segment development research, and related research tourist motivation. The participation of the local community is to support government programs, participate in providing input or suggestions and ideas, maintain the security situation, and participate in maintaining a clean environment for tourist attractions in the border areas of the country. http://ojs.unud.ac.id/index.php/eot
The results of the IFE and EFE matrices show that the country's border area is in the internal and external average position, which means that the country's border area is in quadrant $\mathrm{V}$, the strategy in quadrant $\mathrm{V}$ is to hold and maintain. Quadrant V shows that the country border area in Jayapura City has developed and needs to be maintained, so the right strategies to be applied are market penetration and product development.

Based on the identification of internal and external factors that affect the development of national border areas, the strategy for developing state border areas is the SO (Strengths-Opportunities) Strategy, making a special polarization mapping for tourism development in the border areas of the country, maximizing the types and diversity of tourism products in the border areas of the country, and evaluating the cross-border festival in order to increase the number of tourist visits from Pacific countries through cross-country borders. WO (Weaknesses-Opportunities) strategy, dissemination and training in developing human resources, especially local communities, building public facilities and special tourism facilities, and improving coordination between stakeholders. The WT (Weaknesses-Threats) strategy, conducts focus group discussions, seminars, workshops, training local people for entrepreneurship, improves formal e-ISSN: 2407-392X. p-ISSN: 2541-0857 
education for local youths, collaborates with other parties such as environmental activists, environmentalists, government and other private parties related to waste handling at each tourist attraction, and existing regulations should be evaluated and enforced.

National border area development program, with Strengths-Opportunities: mapping and polarization of tourist attractions, maximizing the types and diversity of tourism products in the border areas of the country, and evaluating crossborder festivals, development programs with Weaknesses-Opportunities: dissemination and training for human resource development, especially local communities, development of public facilities, tourism infrastructure, and coordination between stakeholders, and development programs with WeaknessesThreats: focus group discussions, seminars, workshops, entrepreneurship training, formal education for local youth, safety and hygiene of tourist attractions, and regulatory evaluation.

\section{Suggestions}

Suggestions that can be given are that the government should develop tourism infrastructure and evaluate local regulations, second: ASITA should promote tourism potential in the border areas of the country, third: the Indonesian http://ojs.unud.ac.id/index.php/eot
Tour Guides Association should carry out guide training for local communities, fourth: regional tourism consultants should conduct research on the tourism market segment and research on the motivation of tourists in the border areas of the country, and fifth: local people should support government programs, provide suggestions or input and ideas, and participate in maintaining the security and cleanliness of the environment for tourist attractions in border areas. The results of the IFE, EFE and IE matrix analysis show that the position of the border region of the country is in a medium internal and external condition. Therefore, the right strategies to be applied are market penetration and product development.

The right programs that can be carried out related to the development of country border areas, namely first: mapping and polarization of tourist attractions and evaluation of cross-border festivals. The second program: dissemination and training on human resource development, especially local communities, construction of public facilities, tourism infrastructure, and coordination between stakeholders. Third program: focus group discussions, seminars, workshops, entrepreneurial training, formal education for local youth, safety, and hygiene of tourist attractions, and evaluation of local regulations. 


\section{ACKNOWLEDGED}

The author would like to thank Dr. Drs. I Nyoman Sunarta, M.Si. as the Dean of the Faculty of Tourism, Udayana University and Dr. Ir. I Gusti Ayu Oka Suryawardani, M.Mgt., Ph.D. as the Coordinator of the Udayana University Tourism Masters Study Program. The author also thanks Ir. A. A. P. Agung Suryawan Wiranatha, M.Sc., Ph.D. as the first supervisor and Dr. Ida Bagus Gde Pujaastawa, MA. as the supervisor II who has guided the author from beginning to end. The author's gratitude goes to central and local government officials, leaders of local tourism associations or institutions, and leaders of local community customary institutions for providing data and information related to the development of the country's border areas.

\section{REFERENCES}

Ariani, Ni K.D. dan I.B. Suryawan. 2018. Perencanaan Pengembangan Kawasan Pariwisata Pantai Lebih, Desa Lebih, Kabupaten Gianyar. Jurnal Destinasi Pariwisata. Vol. 6, No. 2, hlmn. 258-263. E-ISSN: 25488937.

Afrianto, S.Y., P.G. Wiloso dan G. Sasongko. 2017. Evaluation of the Implementation of Tourism Policy. Vol. 21, No.1, hlmn. 76-98.

http://ojs.unud.ac.id/index.php/eot
Antariksa, Basuki. 2016. Kebijakan Pembangunan Kepariwisataan. Malang Jawa Timur: Intrans Publishing.

Ardana, I Gusti Gede. 2007. Pemberdayaan Kearifan Lokal Masyarakat Bali dalam Menghadapai Budaya Global. Denpasar: Pustaka Tarukan.

Arjana, I Gusti Bagus. 2015. Geografi Pariwisata dan Ekonomi Kreatif. Jakarta: Rajagrafindo Persada.

Butler, R.W. 1980. The Concept of a Tourist Area Cycle of Evolution: Implication for Management of Resources. Canadian Geographer, XXIV, 1: 5-12. University of Western Ontario.

Damanik, J. dan F. H. Weber. 2006. PERENCANAAN EKO WISATA dari Teori ke Aplikasi. Yogyakarta: CV. ANDI OFFSET.

David, Fred R and Forest. R. David. 2017. Strategic Management: A Competitive Advantage Approach, Concepts and Cases, $16^{\text {th }}$ Edition. London: Pearson Education, Inc.

Dewi, M.A., I. Rachmawati., S. Issundari dan M. Sugiarto. 2020. Developing Border Tourism in Sota, Merauke through Tourism Festival. Athens Journal of Tourism. Vol. X, No. Y. pp. 1-13.

Francos, V. dan B. Lionel. 2008. Pemasaran Pariwisata Internasional: Sebuah Pendekatan Strategis. Jakarta: Yayasan Obor Indonesia.

Skäremo, Gustav. 2016. Cross-border Tourism Development: A Case of the Öresund Region. Umeå University: Department of Geography and Economic. Master Thesis in Human Geography.

e-ISSN: 2407-392X. p-ISSN: 2541-0857 
Kodhyat, H. dan Ramaini. 1992. Kamus Pariwisata dan Perhotelan. Jakarta: Grasindo.

Kusherdyana. 2013. Pemahaman Lintas Budaya dalam Konteks Pariwisata dan Hospitality. Bandung: Alfabeta.

Kurniadi, Dendy. 2009. Strategi Pengembangan Wilayah Perbatasan antarnegara: Memacu Pertumbuhan Ekonomi Entikong Kabupaten Sanggau Provinsi Kalimantan Barat. Universitas Diponegoro Semarang. Tesis.

Mediun, I Nyoman. 2010. Nusa Dua Model Pengembangan Kawasan Wisata Modern. Bali: Udayana University Press.

Martins, Zeferino, S.A. Paturusi. dan I.B.K. Surya. 2017. Peran Pemerintah dalam Pengembangan Potensi Pariwisata di Area Branca Metiaut Dili. Jurnal Magister Pariwisata (JUMPA). Vol, 3, No. 2. hlm. 372-386.

Nurdiyansah. 2014. Peluang dan Tantangan Pariwisata Indonesia. Bandung : ALFABETA.

Pitana, I G. dan Putu G. Gayatri. 2005. Sosiologi Pariwisata. Bandung: Andi

Pitana, I G. dan I K.S. Diarta. 2009. Pengantar Ilmu Pariwisata. Yogyakarta: Andi.

Rangkuti, Fredy. 2001 Analisis SWOT Teknik Membedah Kasus Bisnis. Jakarta: PT. Gramedia Pustaka Utama.

Sugiyono. 2007. Metodologi Penelitian Bisnis. Jakarta: PT. Gramedia.

Sugiyono. 2014. Metode Penelitian Pendidikan Pendekatan Kuantitatif, Kualitatif, dan $R \& D$. Bandung: Alfabeta.

Suandy, Erly. 2001. Perencanaan Pajak. Jakarta: Salemba Empat.

Suardana, I Wayan. 2013. ANALISIS KEBIJAKAN PENGEMBANGAN PARIWISATA (Intervensi Melalui Kebijakan Pariwisata Berkelanjutan di Bali). Paper Seminar Nasional Pariwisata Berlanjutan, diselenggarakan oleh Program S3 Pariwisata Unud, 2 Mei 2013.

Suwantoro, Gamal. 2004. Dasar-Dasar Pariwisata. Yogyakarta: ANDI.

Sunaryo, Bambang. 2013. Kebijakan Pembangunan Destinasi Pariwisata Konsep dan Aplikasinya. Yogyakarta: Gava Media.

Soekadijo, R. J. 1996. ANATOMI PARIWISATA sebagai Systemic Lingkage. Jakarta: PT Gramedia Pustaka Utama.

Sholihah, Imas. 2016. Kebijakan Hukum Pembangunan Kawasan Perbatasan Melalui Infrastruktur Berbasis Teknologi. Jurnal Rechtsvinding. Vol. 5, No. 3, hlmn. 307-321. ISSN: 2089-9009.

Utama, I G.B.R dan Ni M.E. Mahadewi. 2012. Metodologi Penelitian Pariwisata dan Perhotelan. Yogyakarta: Andi.

Widiatedja, I G.N.P. 2011. Kebijakan Liberalisasi Pariwista Konstruksi Konsep, Ragam Masalah dan Alternatif Solusi. Bali: Udayana University Press.

Yuliani, S., W. Setyaningsih dan Y. Winarto. 2018. Strategi Penataan Kawasan Pantai Klayar Pacitan sebagai Destinasi Pariwisata Berkelanjutan dengan Prinsip Arsitektur Ekologis. Jurnal RUAS. Vol. 16, No. 2, hlmn. 1-12. E-ISSN: 2477-6033.

e-ISSN: 2407-392X. p-ISSN: 2541-0857 